\title{
Suicide in indigenous and non-indigenous population: a contribution to health management
}

\author{
Suicídio na população indígena e não indígena: uma contribuição para a gestão em saúde \\ Suicidio en la población indígena y no indígena: una contribución para la gestión en salud
}

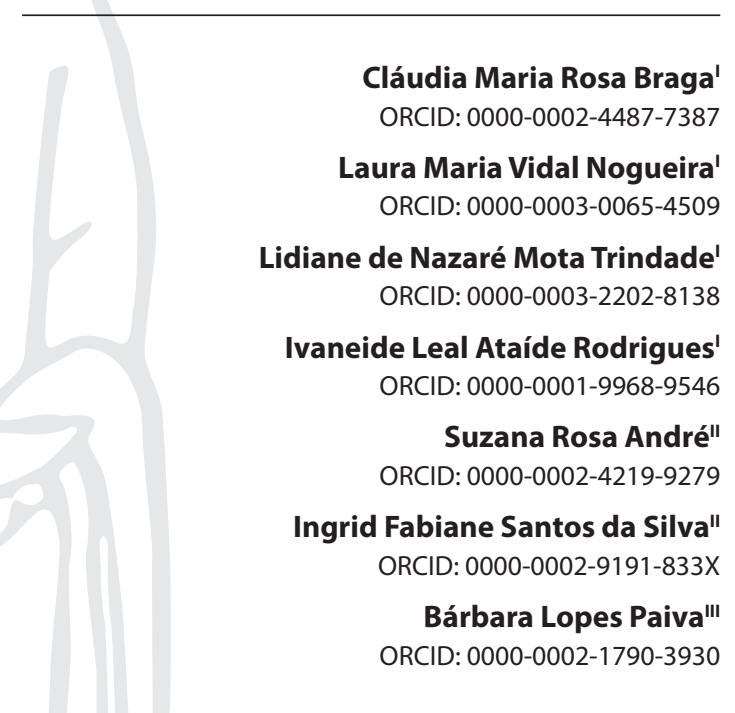

'Universidade do Estado do Pará. Belém, Pará, Brazil. "Universidade Federal do Rio de Janeiro. Rio de Janeiro, Rio de Janeiro, Brazil.

I'Universidade Federal do Pará. Belém, Pará, Brazil.

How to cite this article: Braga CMR, Nogueira LMV, Trindade LNM, Rodrigues ILA, André SR, Silva IFS, et al. Suicide in indigenous and non-indigenous population: a contribution to health management.

Rev Bras Enferm. 2020;73(Suppl 1):e20200186. doi: http://dx.doi.org/10.1590/0034-7167-2020-0186

\section{Corresponding author:} Suzana Rosa André

E-mail: suzanarandre@gmail.com

EDITOR IN CHIEF: Antonio José de Almeida Filho ASSOCIATE EDITOR: Hugo Fernandes

\section{ABSTRACT}

Objective: To analyze the sociodemographic and epidemiological profile of suicide in the indigenous and non-indigenous population and the spatiality of the event. Method: Epidemiological, descriptive research, carried out with data from the Mortality Information System. Suicide mortality rates were calculated for the 144 municipalities in Pará and linked to the geographic location values of the municipalities; subsequently, thematic maps were built using the QGIS 3.10 .3 software. The association between variables was measured by the $\mathrm{G}$ test. Results: 1,387 suicide records were studied, and the mortality rate among indigenous people was low in comparison to non-indigenous people, reaching $0.1 / 100$ thousand inhabitants and 17.5/100 thousand inhabitants, respectively. Conclusion: Suicide is heterogeneously distributed in the territory, with greater vulnerability of the indigenous people, which demands different policies considering their cultural diversity.

Descriptors: Indigenous Population; Suicide; Health Management; Spatial Analysis; Health Status Disparities.

\section{RESUMO}

Objetivo: Analisar o perfil sociodemográfico e epidemiológico de suicídio na população indígena e não indígena e a espacialidade do evento. Método: Estudo epidemiológico, descritivo, realizado com dados do Sistema de Informação sobre Mortalidade. Foram calculadas taxas de mortalidade por suicídio para os 144 municípios do Pará e relacionadas com os valores de localização geográfica dos municípios; posteriormente, foram construídos mapas temáticos utilizando o software $Q G / S$ 3.10.3. A associação entre as variáveis foi medida pelo teste G. Resultados: Foram estudados 1.387 registros de suicídio, e a taxa de mortalidade entre indígenas mostrou-se baixa em relação aos não indígenas, alcançando 0,1/100 mi habitantes e 17,5/100 mil habitantes, respectivamente. Conclusão: O suicídio está distribuído heterogeneamente no território, com maior vulnerabilidade de indígenas, o que demanda políticas diferenciadas considerando sua diversidade cultural.

Descritores: População Indígena; Suicídio; Gestão em Saúde; Análise Espacial; Disparidades nos Níveis de Saúde.

\section{RESUMEN}

Objetivo: Analizar el perfil sociodemográfico y epidemiológico de suicidio en la población indígena y no indígena y el espacio del evento. Método: Estudio epidemiológico, descriptivo, realizado con datos del Sistema de Información sobre Mortalidad. Han calculadas tasas de mortalidad por suicidio para los 144 municipios de Pará y relacionadas con los valores de ubicación geográfica de los municipios; posteriormente, han sido construidos mapas temáticos utilizando el software QGIS 3.10.3. La asociación entre las variables ha sido medida por el test G. Resultados: Ha sido estudado 1.387 registros de suicidio, y la tasa de mortalidad entre indígenas se mostró baja en relación a los no indígenas, alcanzando $0,1 / 100$ mil habitantes y 17,5/100 mil habitantes, respectivamente. Conclusión: El suicidio está distribuido heterogéneamente en el territorio, con mayor vulnerabilidad de indígenas, lo que demanda políticas diferenciadas considerando su diversidad cultural.

Descriptores: Población Indígena; Suicidio; Gestión en Salud; Análisis Espacial; Disparidades en los Niveles de Salud. 


\section{INTRODUCTION}

Suicide has been described as an increasingly frequent problem in social spaces, representing an important public health issue that affects individuals from different population groups, age groups, sex, and religions ${ }^{(1-3)}$. Data from the World Health Organization (WHO) indicates that more than 800 thousand people die every year worldwide because of this event, which means one death every 40 seconds ${ }^{(4)}$.

In Brazil, suicide is among the top ten causes of death, being the third among people aged 20 to 39 years ${ }^{(5)}$. In the period from 2011 to 2015, across the country, there were 55,649 deaths from suicide, with a rate of $5.5 / 100$ thousand inhabitants, varying from 5.3/100 thousand inhabitants in 2011 to 5.7/100 thousand inhabitants in 2015. The highest rates were observed in people aged 70 and over, reaching 8.9/100 thousand inhabitants ${ }^{(6)}$.

For the indigenous population, in the same period from 2011 to 2015 , the suicide rate was $15.2 / 100$ thousand inhabitants. The highest proportion was identified among adolescents aged 10 to 19 , corresponding to $44.8 \%$ of the total recorded in the period, a value eight times greater than that observed among whites and blacks, which was $5.7 \%$ for each group ${ }^{(6-7)}$.

Indigenous suicide has increased in recent years. Data provided by the Special Secretariat for Indigenous Health (SSIH) indicate that, in the Special Indigenous Health District (SIHD) of Mato Grosso do Sul, there were 782 deaths from self-harm between 2000 and 2016, which may be related to the difficulty in the integration process with western society, as well as the social vulnerability issues to which they are submitted ${ }^{(7-9)}$.

Deaths by suicide can differ between ethnic groups and between urban and rural areas, referring to the social and cultural dimension ${ }^{(8-10)}$. The heterogeneous geographic distribution of suicide has persisted over time, both in countries and in the geographic spaces within the same country, which led to the hypothesis that suicide is correlated with the territory ${ }^{(11-13)}$.

The analysis of events considering the geographical area in which they occur has been increasingly valued in health management, as it provides better knowledge of their distribution in space, contributing to the identification of areas where a priority can be given for intervention (14-15).

\section{OBJECTIVE}

Analyze the sociodemographic and epidemiological profile of suicide in the indigenous and non-indigenous population and the spatiality of the event.

\section{METHODS}

\section{Ethical aspects}

The study complied with the recommendations of Resolution No. 466/12 - CNS/MS, which regulates research involving human beings, approved by the Research Ethics Committee of the Undergraduate Nursing Course at the State University of Pará (UEPA).

\section{Design and place of study}

An epidemiological, descriptive study, using the Strengthening the Reporting of Observational Studies in Epidemiology (STROBE) (16) as a methodological guide, conducted in the state of Pará, in the Amazon region of Brazil. Pará consists of 144 municipalities and concentrates 34 indigenous ethnic groups distributed in 298 villages, totaling approximately 39,081 indigenous people ${ }^{(17)}$.

\section{Study population and period}

The study population was of 1,387 suicide cases reported in the municipalities of the state of Pará from 2010 to 2015 and whose basic cause was coded as intentional self-harm (codes X60 to X84), according to the International Statistical Classification of Diseases and Health Problems (ICD-10).

\section{Data collection and source}

Suicide cases in the municipalities of the state of Pará were collected in the Mortality Information System (MIS), made available by the Health Surveillance Coordination (HSC) of the State Secretariat of Public Health of Pará (SSPHP).

For the calculation of the mortality rate, we used estimated data for the population of the years 2011, 2012, 2013, 2014, and 2015, made available by DATASUS (Information Technology at the service of the Brazilian Unified Health System referred to as SUS) ${ }^{(18)}$. And the 2010 population data was taken from the 2010 census (19). Also, from the Brazilian Institute of Geography and Statistics $(\mathrm{IBGE})^{(20)}$, shapefiles were obtained for the preparing of the maps.

\section{Data analysis}

After the database was made available by the SSPHP's HSC, the file was structured in Microsoft Office Excel ${ }^{\circledR} 2010$ and then the variables were organized: municipality of residence; sex; age; marital status; and schooling. The data were grouped into two banks according to race/color, identifying indigenous and nonindigenous people. Subsequently, the analysis was structured in two stages: statistical analysis and spatial analysis.

For the statistical analysis, mortality rates were calculated by the expression: Number of suicides/absolute population $\times 100$ thousand inhabitants. The population data was the result of the average number of inhabitants for each year of the studied period, using population estimates and the 2010 demographic census of the IBGE. A $95 \%$ confidence interval $(95 \% \mathrm{Cl})$ was considered.

Then, demographic characterization was performed based on the following variables: sex; marital status; schooling; and age. The $\mathrm{G}$ test was used to compare the proportions of the demographic variables of indigenous and non-indigenous groups. Statistical significance was set at $p<0.05$, and the analyzes were performed using the Bioestat 5.0 software.

For spatial analysis, the Federative Unit, that is, the state of Pará, was established as a territorial section, and as a geographical unit of analysis, the municipality. Thus, the 144 municipalities in Pará were studied. The mortality rate was calculated using data stratified in two trienniums (2010 to 2012 and 2013 to 2015), whose values 
were obtained by the sum of the cases (indigenous and nonindigenous) of each triennium divided by the population median of the triennium, calculated by the IBGE estimate for each year and multiplied by 100,000 inhabitants, according to the formula ${ }^{(21)}$ :

$$
\begin{gathered}
\text { Rate }_{\text {non-indigenous }}=\frac{1}{\tilde{T}} \sum^{T} C_{\text {non-indigenous }} * 100000 \\
\text { Rate }_{\text {indigenous }}=\frac{1}{\tilde{T}} \sum^{T} C_{\text {indigenous }} * 100000
\end{gathered}
$$

Where $T$ is the triennium, $\tilde{T}$ is the median population for the triennium, and $C$ is the number of cases.

To standardize the occurrence of suicide according to sex and age, indirect standardization was used under the justification of a considerable difference between the orders of magnitude of the indigenous and non-indigenous populations. The calculation of the standardized rate was performed according to Lwanga ${ }^{(22)}$ :

$$
\begin{aligned}
& \text { Standardized rate }_{i}=F P_{i} \times I M_{i} \\
& F P_{i}=\frac{\text { Rate }_{\text {Non-indigenous }}}{I M_{i}} \\
& I M_{i}=\frac{\sum_{j} P_{i j} \times \text { Rate }_{j}}{P_{i}} \times 100,000
\end{aligned}
$$

We have $i$ as an indicator of indigenous population, FP corresponds to the standardization factor, IM corresponds to the mortality index, and Rate and $\mathrm{P}$ are the mortality rate and the population for each evaluated segment, respectively.

The calculation of the crude rate for comparative analysis followed the formula:

$$
\text { Crude rate }_{i}=\frac{\sum_{j} \times \text { Suicide cases }_{i}}{P_{i}} \times 100,000
$$

For population, data segmented by color/race, sex, and age group provided by the 2010 Demographic Census (Table 3175 - available at https://sidra.ibge.gov.br/Tabela/3175) were used, under the premise that there was no significant variation in the age and sex profile of the populations evaluated. The 12 suicide observations that did not have information on age group and, one case without information on sex, were disregarded in this calculation, as these data referred to the group of non-indigenous people.

The suicide mortality rates for each municipality were linked to the geographic location values (latitudes and longitudes) of each municipality, obtained from the IBGE website, which allowed the construction of thematic maps using the QGIS 3.10.3 software. The rates were grouped into five ranges, both for indigenous and non-indigenous, and categorized based on the criteria suggested by Diekstra and Gulbinat ${ }^{(23)}$ in: null; low (0.1-4.9); average (5.0-14.9); high (15.0-29.9); and very high (> 30.0).

\section{RESULTS}

1,387 suicide cases were analyzed during the study period. According to Table 1, the suicide mortality rate for the non-indigenous population was 17.5/100 thousand inhabitants, with an average of 231 cases each year ( $\mathrm{Cl} 229.6$ - 232.3), with the highest rate in 2015 with $3.8 / 100$ thousand inhabitants. Regarding the indigenous population, the mortality rate was $0.1 / 100$ thousand inhabitants, (Cl 0.3 - 1.6) with low rates.

Table 2 shows the sociodemographic profile of suicide in the two groups studied. It was identified that the proportion of the event in the non-indigenous population was higher among men, with $80.43 \%$ ( $n=1,110$ cases); and in the indigenous population, among women, corresponding to $57.14 \%(n=4)$ of the cases.

Regarding the age group, it was found that, among non-indigenous people, $28.99 \%(n=400)$ of the cases occurred in people aged between 20 and 29 years, while in the indigenous population, the largest number of cases occurred in the age groups between 30 and 39 years, and 80 years or more, both with $28.57 \%(n=2)$.

Regarding marital status, the results showed that suicide prevailed among individuals that were single in both populations, corresponding to $61.59 \%(n=850)$ among non-indigenous people and $57.14 \%(n=4)$ among indigenous people.

In regard to education, a greater expressiveness was observed among those with 4 to 7 years of study, with $29.06 \%(n=401)$ of the total cases. For the indigenous population, the data showed a predominance among individuals with no education with $28.57 \%$ $(n=2)$. It is important to highlight the considerable number of non-filled "schooling" field in the data for the indigenous population, adding to a total of $28.57 \%(n=2)$.

According to Table 3, the comparison of crude rates with standardized rates, by age group, allows us to identify that indigenous people have a higher calculated value. The composition of populations according to age group shows a higher proportion of non-indigenous individuals in the groups with the highest suicide rates (from 20 years old). This would justify the higher crude rate of non-indigenous people.

The standardization according to sex did not show any changes, indicating that the composition of both populations is similar, showing little influence when comparing.

The stratified rates showed that, for the three-year period, from 2010 to 2012, for the indigenous population, the highest values were in the municipalities of Alenquer, Itaituba, Cametá, and Tucumã, ranging from $0.1 / 100$ thousand inhabitants to $4.9 / 100$ thousand inhabitants;

\begin{tabular}{|c|c|c|c|c|c|c|c|c|}
\hline$N^{\circ}$ of Cases and Rate (Suicide) & 2010 & 2011 & 2012 & 2013 & 2014 & 2015 & Total & IC 95\% \\
\hline $\mathrm{N}^{\circ}$ of cases (Non-indigenous) & 192 & 228 & 246 & 234 & 213 & 267 & 1380 & \multirow{2}{*}{$(229.6-232.3)$} \\
\hline TS / year & 3.0 & 3.5 & 3.7 & 3.5 & 3.1 & 3.8 & 17.5 & \\
\hline No of cases (Indigenous) & 1 & 1 & 2 & 0 & 2 & 1 & 7 & \multirow{2}{*}{$(0.3-1.6)$} \\
\hline TS / year & 0.0 & 0.0 & 0.0 & 0.0 & 0.0 & 0.0 & 0.1 & \\
\hline
\end{tabular}
and for the three-year period, from 2013 to 2015 , the municipalities with the highest suicide rates were Altamira, Jacareacanga, and Portel (Figure 1). In both periods, rates were classified as low.

Table 1 - Suicide incidence rate among indigenous and non-indigenous populations in the state of Pará, from 2010 to 2015, Pará, Brazil, 2019

Source: MIS/HSC/SSPHP, 2018.

Notes: $T S=$ Suicide Mortality Rate $; \bar{X}($ non-indigenous $)=231$ cases $; \bar{X}($ indigenous $)=1$ case . 
Table 2 - Distribution of suicide cases among indigenous and non-indigenous populations, according to sociodemographic variables, 2010-2015, Pará, Brazil, 2019

\begin{tabular}{|c|c|c|c|c|c|}
\hline \multirow{2}{*}{ Variable } & \multicolumn{2}{|c|}{$\begin{array}{c}\text { Non-indigenous } \\
(1.380)\end{array}$} & \multicolumn{2}{|c|}{$\begin{array}{l}\text { Indigenous } \\
\text { (7) }\end{array}$} & \multirow{2}{*}{$p$ value* } \\
\hline & $\mathbf{n}$ & $\%$ & $\mathbf{n}$ & $\%$ & \\
\hline \multicolumn{6}{|l|}{ Sex } \\
\hline Male & 1.110 & 80.43 & 3 & 42.86 & \multirow{3}{*}{$0.072^{* *}$} \\
\hline Female & 269 & 19.5 & 4 & 57.14 & \\
\hline lgnored ${ }^{\ddagger}$ & 1 & 0.07 & 0 & 0.00 & \\
\hline \multicolumn{6}{|l|}{ Age Group } \\
\hline$<04$ & 0 & 0.00 & 0 & 0.00 & \multirow{12}{*}{1.000} \\
\hline 05-09 & 3 & 0.22 & 0 & 0.00 & \\
\hline $10-14$ & 43 & 3.12 & 1 & 14.29 & \\
\hline $15-19$ & 157 & 11.38 & 1 & 14.29 & \\
\hline $20-29$ & 400 & 28.99 & 1 & 14.29 & \\
\hline $30-39$ & 323 & 23.41 & 2 & 28.57 & \\
\hline $40-49$ & 187 & 13.55 & 0 & 0.00 & \\
\hline $50-59$ & 128 & 9.28 & 0 & 0.00 & \\
\hline $60-69$ & 76 & 5.51 & 0 & 0.00 & \\
\hline $70-79$ & 36 & 2.61 & 0 & 0.00 & \\
\hline $80 \mathrm{e}+$ & 15 & 1.09 & 2 & 28.57 & \\
\hline lgnored $^{\ddagger}$ & 12 & 0.87 & 0 & 0.00 & \\
\hline \multicolumn{6}{|c|}{ Marital status } \\
\hline Single & 850 & 61.59 & 4 & 57.14 & \multirow{5}{*}{0.163} \\
\hline Married & 215 & 15.58 & 0 & 0.00 & \\
\hline Widower & 29 & 2.10 & 2 & 28.57 & \\
\hline Separate & 27 & 1.96 & 0 & 0.00 & \\
\hline lgnored ${ }^{\ddagger}$ & 259 & 18.77 & 1 & 14.29 & \\
\hline \multicolumn{6}{|c|}{ Education level } \\
\hline None & 145 & 10.51 & 2 & 28.57 & \multirow{6}{*}{0.662} \\
\hline $1-3$ & 328 & 23.77 & 1 & 14.29 & \\
\hline $4-7$ & 401 & 29.06 & 1 & 14.29 & \\
\hline $8-11$ & 284 & 20.58 & 1 & 14.29 & \\
\hline$\geq 12$ & 79 & 5.72 & 0 & 0.00 & \\
\hline lgnored ${ }^{\ddagger}$ & 143 & 10.36 & 2 & 28.57 & \\
\hline
\end{tabular}

Source: MIS/HSC/SSPHP, 2018.

Notes: ** G Test $(p<0,05) ;{ }^{* *}$ Significant difference; ${ }^{*}$ Values not included in the statistical analysis.

Table 3 - Suicide mortality rate in the indigenous and non-indigenous population, standardized by age group and sex, 2010-2015, Pará, Brazil, 2019

\begin{tabular}{lcc}
\hline & \multicolumn{2}{c}{ Population } \\
& Non-indigenous & Indigenous \\
\hline Crude Rate & 18.3 & 17.9 \\
Standardized rate by age group & 18.1 & 21.1 \\
Standardized rate by sex & 18.3 & 17.9 \\
\hline Source: MIS/HSC/SSPHP, 2018. & &
\end{tabular}

Source: MIS/HSC/SSPHP, 2018.

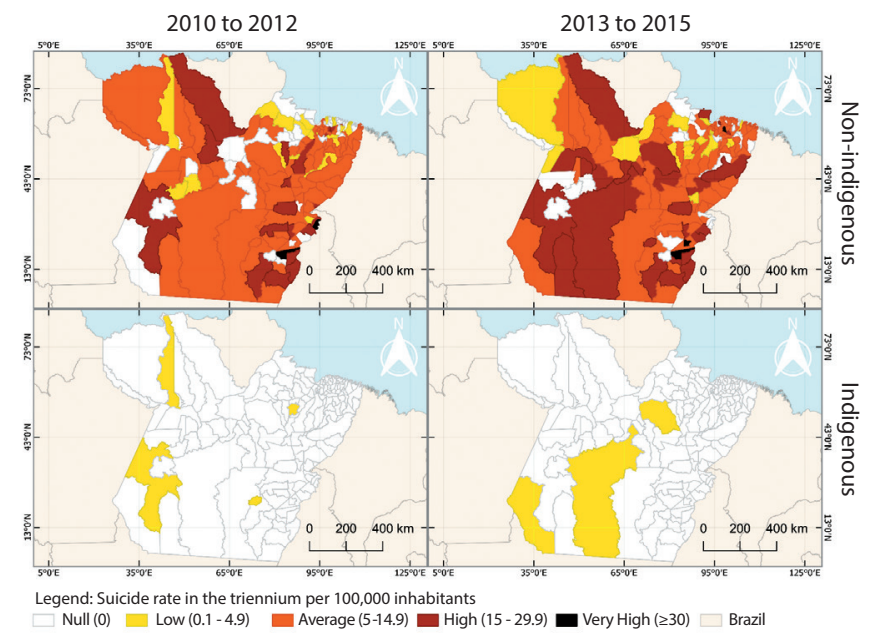

Figure 1 - Mortality rate due to suicide in the indigenous and non-indigenous population of the state of Pará by municipality, in the period of 2010-2015, Pará, Brazil, 2019
For the non-indigenous population, in the period of 2010 to 2012 , suicides were recorded in $73.61 \%$ of the municipalities in Pará, highlighting the high rates in the municipalities Abel Figueiredo (29.2/100 thousand inhabitants), Brejo grande do Araguaia (27.4/100 thousand inhabitants), Cumaru do Norte (27.2/100 thousand inhabitants), and Moju (28/100 thousand inhabitants). During this study period, the municipalities in the very high range were Rio Maria (33.9/100 thousand inhabitants) and Palestina do Pará (40.3/100 thousand inhabitants).

In the three-year period, from 2013 to 2015, the data indicate a significant increase in suicide mortality rates in municipalities previously classified in the middle range, which migrated to the high range, namely: Altamira, Novo Progresso, Portel, Uruará, and Paragominas.

\section{DISCUSSION}

The analysis of the data allowed to identify that, in the studied period, the indigenous people had lower suicide rates, causing the occurrence of possible underreporting in the records ${ }^{(8-9)}$. There was also evidence of heterogeneity of rates in the geographic spaces of the municipalities of Pará.

Regarding the dynamics of the event's occurrence in Brazil, although data points to higher rates in the South Region ${ }^{(24-26)}$, the North and Northeast Regions have shown a growth trend in recent years ${ }^{(6,12)}$. A study carried out in Sergipe ${ }^{(27)}$ identified an increase of $102.3 \%$ in the suicide mortality rate between 2000 and 2015 , from 2.69/100 thousand inhabitants in 2000 to 5.44/100 thousand inhabitants in 2015. In the North Region, there was an increase from 3.8/100 thousand in the year 2000 to 5.3/100 thousand in the year 2012, impacting the national indexes ${ }^{(28)}$. This scenario has contributed to changes in the pattern of morbidity and mortality of the Brazilian population in recent years, which has been registering a decline in mortality from infectious diseases and an increase in external causes, including suicide ${ }^{(26)}$.

The analysis of the "sex" variable denotes a predominance among men for non-indigenous population and in women for indigenous, although the standardized rate has indicated similarity in the occurrence of the event in both population groups. The identified result draws attention, since the literature refers to higher rates among men in the two groups studied and points out that, in the female population, the rates are higher in relation to suicide attempt whose outcome does not always correspond to death ${ }^{(8-10,27)}$. In this sense, the study carried out in Roraima, when analyzing suicide between indigenous and nonindigenous people, identified in the first group rates of 20.3/100 thousand for men and 9.3/100 thousand for women; and among non-indigenous people, rates of 12.9 and 4.2/100 thousand, for men and women, respectively ${ }^{(8)}$.

The higher occurrence among men indicates coherence with the explanations about male behaviors related to competitiveness, greater aggressiveness, as well as easy access to firearms, and difficulties in facing unfavorable economic situations ${ }^{(28-30)}$. Strengthening this analysis, studies report that women present a lower alcohol dependency, more religiosity, early perception of risk signs for depression and mental illness by using the health service and help networks in times of crisis ${ }^{(1,30-31)}$. 
Another important factor to be valued is related to the suicide modalities chosen by men, with the use of firearms and hanging, as they present greater lethality. Women use more intoxication methods by poison or medication. This would explain the higher mortality among men and the many attempts among women ${ }^{(29,31-33)}$.

In this study, there was a significant number of suicide cases in young adults, aged between 20 and 39 years, both in indigenous and non-indigenous groups, with an additional for the indigenous population of the event in the elderly over 80 years. The comparison between crude and standardized rates indicated a larger dimension of the event in older age groups in the group of non-indigenous people. In this sense, although researchers ${ }^{(9,31,33-34)}$ attribute suicide to the socio-cultural context in which people are inserted, strengthening the idea of the influence of the environment in its occurrence, the reasons that lead to the practice of suicide may vary depending on age group.

Among young people and adults, disruption of relationships, difficulties in entering the labor market, socioeconomic factors, difficulties in adapting to contemporary transformations, family instability, and excessive consumption of alcohol and other drugs are the main causes ${ }^{(1,23,35)}$. And in the elderly population, suicide is attributed to abandonment by family members, social isolation, the emergence of chronic diseases, loss of loved ones, and the proximity of death ${ }^{(36-37)}$.

Regarding marital status, singles had the highest rates in both ethnic groups, confirming the results described in the literature ${ }^{(8-9,31,35)}$, leading to the inference that the "single" variable is a contributing factor to the practice of suicide in both populations. In this sense, it is admitted that the absence of an affective bond contributes to emotional vulnerability, making it difficult to cope with adverse everyday situations, which makes the individual more prone to the practice of self-harm ${ }^{(29)}$. It is important to emphasize that family ties, work, and social obligations strengthen people by reducing their weaknesses and, consequently, their vulnerability to suicide ${ }^{(33)}$.

The level of education, likewise, is a relevant variable in studies on suicide, showing itself associated with the event, although with different analyzes for the two groups studied. Among indigenous people, suicide proved to be more expressive in people with no schooling and with few years of study, reinforcing other research, in view of the low schooling profile present in indigenous communities. This situation is attributable to the restricted access to formal education, which is still a factor in Brazil(8-10,38).

In this context, the high number of notifications where the data age field was not filled in, this population group stands out. The incompleteness of the records in the information system precludes further analysis of the problems, making it difficult to understand the real scenario and, consequently, to plan preventive actions. In this specific case, we can argue that such a gap in filling is due to the difficulty of obtaining the data from the informant at the time of death registration.

In this study, among non-indigenous people, the suicide rate predominated in people with 4 to 7 years of study, considered to be a low educational level. It is admitted that people with less education usually experience low socioeconomic conditions, greater social exclusion and, therefore, greater impairment of individual and family quality of life. The level of education, insertion in the job market, and family income define the social and economic status of the individual, exposing him to different levels of stress $^{(23)}$.

Nevertheless, higher levels of education are described in the literature as social variables capable of potentiating the risk of suicide, given that individuals belonging to higher social groups would be prone to work with higher levels of stress ${ }^{(33-39)}$. The results obtained in this study demonstrated an association between suicide and low education.

With regard to the geographical distribution of suicide in the state of Pará, the rates of occurrence among indigenous people were more expressive, and may be related to conflicts of the most diverse orders, such as: intense approximation with the urbanized population; cultural influence of other ethnic groups; loss of territories; greater exposure to drugs and alcohol ${ }^{(7-8,38)}$. A study carried out in the state of Amazonas highlighted high suicide mortality rates among indigenous people in the municipalities of Santa Izabel do Rio Negro (36.4/100 thousand inhabitants), São Gabriel da Cachoeira (27.6/100 thousand inhabitants), and Tabatinga (25.2/100 thousand inhabitants), possibly due to the increased consumption of alcoholic beverages on weekends, considering that, individuals under the influence of alcohol are more likely to lose their abilities of judgement, self-control, and critical sense and, thus, tend to adopt aggressive behaviors ${ }^{(10)}$.

Indigenous suicide has attracted the attention of scholars, who have linked it with aspects of the cultural devaluation that these people have suffered over the years, inefficiency of differentiated assistance offered by the health sector, social injustices and even loss of their identities ${ }^{(7,34)}$. The cultural factor, therefore, would act synergistically, considering that indigenous culture is based on immediate behavior, that is, without the planning of goals and of future life, hence, life would feel as having little value ${ }^{(10)}$.

Suicide for indigenous people can mean a way to end the suffering, conflicts and anguish that are being experienced. The difficulty of adapting individuals from this ethnic group to urban areas has also been described in the scientific literature as a potentializing factor for the practice of self-inflicted violence ${ }^{(34,40)}$. The indigenous cosmological diversity, in general, explains life as an existential moment prior to what would be "true life" and death as a means by which the soul would abandon the body to live in a more appropriate place ${ }^{(41)}$.

Among non-indigenous people, suicide mortality rates were more expressive in more populous municipalities, reinforcing the idea that conflicts resulting from urbanization and modern life can generate anxiety, social and family disorders, stress, intolerance and disenchantment, which can lead to social isolation arising from the difficulties in dealing with situations identified as impossible to solve ${ }^{(36)}$. Still, it is highlighted that this way of life inhibits the availability for the attentive and solidary look capable of identifying possible emotional changes and suicidal ideations ${ }^{(39-40)}$.

The increase in suicide cases in the municipality of Altamira, both in indigenous and non-indigenous people, can be attributed to the accelerated and intense process of change in the social, geographical, and economic environment installed in the territory since 2010, with the release of the license to install the Belo Monte hydroelectric plant. The announcing of investments in the southwestern region of Pará, as a result of the construction of the hydroelectric plant, boosted the not always successful 
migratory process in search of job opportunities, as well as to the increase in the local population, disordered land occupation, and increased violence. In addition, this undertaking reached indigenous lands, causing a reduction in territory, the need to relocate to other areas and a consequent compromise in the lifestyle of this population ${ }^{(42)}$.

Finally, the analysis revealed inequalities in suicide rates between the indigenous and non-indigenous population, denoting the need for specific actions to prevent this problem. The stratification of suicide throughout the state of Pará, according to the municipalities, allowed the knowledge of the magnitude of the problem in a regionalized way, contributing to plan specific and more effective public policies.

\section{Study Limitations}

The limitations of the study are related to the use of secondary data, therefore, subject to incompleteness and inaccuracies, capable of producing bias in the results. The database offered by the SSPHP did not include the distribution of stratified cases by age group, sex, and education by municipality, nor by indigenous ethnicity.

\section{Contributions to the Area}

For nursing, knowing the reality of individuals who commit suicide and the factors that lead to this outcome is extremely relevant, especially in more vulnerable groups such as the indigenous population. The qualified role of nursing in dealing with this disease that affects people regardless of race/color is a necessity, highlighting that acting in indigenous health requires an understanding of the health-disease process, in addition to knowledge and skills based on interculturality. The importance of deepening studies related to the social, cultural context, and way of life capable of resulting in the occurrence of suicide is emphasized, for the adoption of care measures and preventive practices, in addition to the implementation of public policies aimed at this problem. The training of health professionals to serve different ethnic groups is a necessity that must be prioritized within specific public policies.

\section{CONCLUSION}

The findings made it possible to identify the heterogeneity of suicide in the territory of Pará, as well as the indigenous group being the most vulnerable to the event. In this way, the reality installed in the territorial spaces that characterize people's way of life shows a relationship with the dynamics of suicide and should be valued in the intervention policies and educational practices to promote life.

Public sector incursions into the social and environmental surroundings, especially those of an economic nature, must be carefully planned to minimize the impact and consequences on the lives of local residents and those who migrate in search of opportunities. Such measures are essential to reduce situations of exposure of individuals to factors that trigger stress, anguish, uncertainty, and even despair due to the non-realization of needs, plans, and dreams.

It is worth highlighting the cultural diversity of indigenous populations, which refers to different actions of ethnic appreciation, with the Unified Health System prioritizing actions that contemplate the specificities of life of each human group, culturally signified.

Furthermore, suicide involves factors of the most diverse orders, running through economic, social, cultural, environmental, and interpersonal issues, and must be treated in all its dimensions. In this sense, it is essential to establish institutional partnerships and intersectoral actions, combining efforts to face the problem and reduce its occurrence.

\section{REFERENCES}

1. Ribeiro NM, Castro SS, Scatena LM, Haas VJ. Time-trend analysis of suicide and of health information systems in relation to suicide attempts. Texto Contexto Enferm. 2018;27(2):e2110016. doi: 10.1590/0104-070720180002110016

2. Ribeiro JM, Moreira MR. An approach to suicide among adolescents and youth in Brazil. Ciên Saúde Colet. 2018;23(9):2821-34. doi:10.1590/1413-81232018239.1719 2018

3. Souza MLP. Mortalidade por suicídio entre crianças indígenas no Brasil. Cad Saúde Pública. 2019;35(Suppl 3):e00019219. doi: 10.1590/0102-311X00019219

4. World Health Organization. Mental health: Suicide data[Internet]. 2019[cited 2019 Nov 28]. Available from: http://www.who.int/ mental_health/prevention/suicide/suicideprevent/en/

5. Mata KCR, Daltro MR, Ponde MP. Perfil epidemiológico de mortalidade por suicídio no Brasil entre 2006 e 2015. Rev Psicol Divers Saúde. 2020;9(1):74-87. doi: 10.17267/2317-3394rpds.v9i1.2842

6. Ministério da Saúde (BR). Secretaria de Vigilância em Saúde. Suicídio. Saber, agir e prevenir. Bol Epidemiol[Internet]. 2017 [cited 2019 Sep 28];48(30):1-15. Available from: http://portalarquivos.saude.gov.br/images/pdf/2017/setembro/21/2017-025-Perfil-epidemiologico-dastentativas-e-obitos-por-suicidio-no-Brasil-e-a-rede-de-atencao-a-saude.pdf

7. Conselho Indigenista Missionário. Violência contra os povos indígenas no Brasil [Internet]. 2016 [Cited 2019 Oct 15]. Available from: http:// www.cimi.org.br/pub/Relatorio2016/relatorio2016.pdf

8. Souza MLP, Onety Jr RTS. Characteristics of suicide mortality among indigenous and non-indigenous people in Roraima, Brazil, $2009-2013$. Epidemiol Serv Saúde. 2017;26(4):887-93. doi: 10.5123/S1679-49742017000400019

9. Souza RSB, Oliveira JC, Alvares-Teodoro J, Teodoro MLM. Suicídio e povos indígenas brasileiros: revisão sistemática. Rev Panam Salud Publica. 2020;44:e58. doi:10.26633/RPSP.2020.58 
10. Palma DCA, Santos ES, Ignotti. Análise dos padrões espaciais e caracterização dos suicídios no Brasil entre 1990 e 2015. Cad Saúde Pública. 2020;36(4):e00092819. doi: 10.1590/0102-311X00092819

11. Mota AA. Cartografia do suicídio no Brasil no período 1979-2011. Hygeia (Uberlândia) [Internet]. 2015 [cited 2019 Jun 20];11(20):85-98. Available from: http://www.seer.ufu.br/index.php/hygeia/article/download/27840/16846

12. Wanzinack C, Signorelli MC, Shimakura S, Gomes PP, Pereira PPG, Polidoro M, Oliveira LB. Indigenous homicide in Brazil: geospatial mapping and secondary data analysis (2010 to 2014). Ciênc Saúde Coletiva. 2019;24(7):2637-48. doi: 10.1590/1413-81232018247.23442017

13. Hsu C-Y, Chang S-S, Lee EST, Yip PSF. Geography of suicide in Hong Kong: spatial patterning, and socioeconomic correlates and inequalities. Soc Sci Med. 2015;130:190-203. doi: 10.1016/j.socscimed.2015.02.019

14. Santos, EGO, Barbosa IR, Severo AKS. Análise espaço-temporal da mortalidade por suicídio no Rio Grande do Norte, Brasil, no período de 2000 a 2015. Ciênc Saúde Coletiva. 2020;25(2):633-43. doi: 10.1590/1413-81232020252.11042018

15. Chiaravalloti-Neto F. Geoprocessamento e a Saúde Pública. Arq. Ciênc. Saúde. 2017;23(4) 1-2. doi: 10.17696/2318-3691.23.4.2016.661

16. Von Elm E, Altman DG, Egger M, Pocock SJ, Gøtzsche PC, Vandenbroucke JP, STROBE Initiative. The Strengthening the Reporting of Observational Studies in Epidemiology (STROBE) statement: guidelines for reporting observational studies. J Clin Epidemiol. 2008;61(4):3449. doi: 10.1016/j.jclinepi.2007.11.008

17. IBGE. Instituto de Geografia e Estatística. Censo Demográfico 2010. Rio de janeiro: IBGE, 2010. [Cited 2019 out 15]. Available from: http:// censo2010.ibge.gov.br

18. Ministério da Saúde (BR). Secretaria-Executiva. Departamento de Informática do SUS. Tecnologia da Informação a serviço dos SUS (DATASUS) [Internet]. 2019 [cited 2019 Oct 19]. Available from: http://tabnet.datasus.gov.br/cgi/deftohtm.exe?/cnv/poptbr.def

19. Instituto de Geografia e Estatística (IBGE). Censo Demográfico 2010 [Internet]. 2010 [cited 2019 Oct 30]. Available from: ftp://ftp..gov.br/ Censos/Censo_Demografico_2010/Resultados_do_Universo/xIs/Municipios/para.zip

20. Instituto de Geografia e Estatística. Shapefiles Pará [Internet]. 2010 [cited 2019 Dec 13]. Available from: ftp://geoftp..gov.br/ organizacao_do_territorio/malhas_territoriais/malhas_municipais/municipio_2015/

21. Organização Pan-Americana da Saúde. Indicadores de saúde. Elementos conceituais e práticos. Washington D.C.: OPAS; 2018.

22. Lwanga SK, Tye CY, Ayeni O. Teaching health statistics: lesson and seminar outlines, 2nd ed. Geneva, World Health Organization, 1999.

23. Diekstra RFW, Gulbinat W. The epidemiology of suicidal behavior: a review of three continents. World Health Statist Quat [Internet]. 1993[cited 2019 Dec 13];46(1):52-68. Available from: https://apps.who.int/iris/handle/10665/48670

24. Malta DC, Minayo MC, Soares Filho AM, Silva MMA, Montenegro MMS, Ladeira RM, et al. Mortalidade e anos de vida perdidos por violências interpessoais e autoprovocadas no Brasil e Estados: análise das estimativas do Estudo Carga Global de Doença, 1990 e 2015 . Rev Bras Epidemiol. 2017;20(Suppl-1):142-56. doi: 10.1590/1980-5497201700050012

25. Machado AB, Santos DN. Suicídio no Brasil, de 2000 a 2012. J Bras Psiquiatr. 2015;64(1):45-54. doi: 10.1590/0047-2085000000056

26. Santos EGO, Barbosa IR. Conglomerados espaciais da mortalidade por suicídio no nordeste do Brasil e sua relação com indicadores socioeconômicos. Cad Saúde Colet. 2017;25 (3):371-8. doi: 10.1590/1414-462X201700030015

27. Santos DS, Guimarães LML, Carvalho YF, Viana LC, Alves GL, Lima ACR, Santos MB, Góes MAO, Araújo KCGM. Spatial analysis and temporal trends of suicide mortality in Sergipe, Brazil, 2000-2015. Trends Psychiatry Psychother. 2018;40(4):269-76. doi: 10.1590/2237-6089-2017-0028

28. Corassa RB, Falci DM, Gontijo CF, Machado GVC, Alves PAB. Evolução da mortalidade por causas externas em Diamantina (MG), 2001 a 2012. Cad Saúde Colet. 2017;25 (3):302-14. doi: 0.1590/1414-462X201700030258

29. Orellana JD, Balieiro AA, Fonseca FR, Basta PC, Souza MLP. Spatial-temporal trends and risk of suicide in Central Brazil: an ecological study contrasting indigenous and non-indigenous populations. Rev Bras Psiquiatr. 2016;38(3):222-30. doi:10.1590/1516-4446-2015-1720

30. Pereira AS, Willhelm AR, Koller SH, Almeida RMM. Risk and protective factors for suicide attempt in emerging adulthood. Ciên Saúde Coletiva. 2018;23(11):3767-77. doi: 10.1590/1413-812320182311.29112016

31. Staliano PM , Mondardo ML, Lopes RC. Onde e Como se Suicidam os Guarani e Kaiowá em Mato Grosso do Sul: Confinamento, Jejuvy e Tekoha. Psicol Cien Prof. 2019;39(n.pe):e221674. doi: 10.1590/1982-3703003221674

32. Rodríguez-Hernández JM, Rocha-Buelvas A, Mendieta-Izquierdo G, Hidalgo-Troya A. Riesgo de muerte por suicidio en población colombiana 2000-2013. Ciên Saúde Coletiva. 2018;23(11):3989-96. doi: 10.1590/1413-812320182311.24812016

33. Ribeiro JF, Mascarenhas TB, Araújo ACBS, Coelho DMM, Brancas ABP, Coelho DMM. Perfil sociodemográfico da mortalidade por suicídio. Rev Enferm UFPE. 2018;12(1):44-50. doi: 10.5205/1981-8963-v12i01a25087p44-50-2018

34. Cunha FA, Baptista MN, Carvalho LF. Análise documental sobre os suicídios ocorridos na região de Jundiaí entre 2004 e 2014. Salud Soc. 2016;7(2):212-22. doi: 10.22199/S07187475.2016.0002.00006.

35. Silva ES, Marques Jr J, Sucharas EA. Perfil de suicídios em município da Amazônia Legal. Cad Saúde Colet. 2018;26 (1):84-91. doi: 10.1590/1414-462X201800010135

36. Pereira MM. Representações de suicídio indígena no Amazonas: o que desencadeia a vontade de morrer? Diversitates Int J [Internet]. 2017 [cited 2019 Dec 17];09(1):03-26. Available from: http://www.diversitates.uff.br/index.php/1 diversitates-uff1/article/view/176/110 
37. Souza MLP. Indigenous narratives about suicide in Alto Rio Negro, Brazil: weaving meanings. Saúde Soc. 2016;25(1):145-59. doi: 10.1590/ S0104-12902016145974

38. Pollock NJ, Naicker K, Loro A, Mulay S, Colman. Global incidence of suicide among Indigenous peoples: a systematic review. BMC Medicine. 2018. 16:145. doi: 10.1186/s12916-018-1115-6

39. Santos EGO, Oliveira YOMC, Azevedo UNA, Nunes ADS, Amador AE, Barbosa, IR. Análise espaço-temporal da mortalidade por suicídio em idosos no Brasil. Rev Bras Geriatr Gerontol. 2017;20(6):854-65. doi: 10.1590/1981-22562017020.170115

40. Azuero AJ, Arreaza-Kaufman D, Coriat J, Tassinari S, Faria A, Castañeda-Cardona C, et al . Suicide in the Indigenous Population of Latin America: a systematic review. Rev Colomb Psiquiatr. 2017;46 (4):237-242. doi: 10.1016/j.rcp.2016.12.002

41. Galvão PVM, Silva HRS, Silva CMFP. Temporal distribution of suicide mortality: a systematic review. J Affective Dis. 2018;228:132-42. doi: 10.1016/j.jad.2017.12.008

42. Simoni AT, Dagnino RS. Dinâmica demográfica da população indígena em áreas urbanas: o caso da cidade de Altamira, Pará. Rev Bras Est Pop. 2016;33(2)43-51. doi:10.20947/S0102-30982016a0020 